\title{
Machine Learning for Solving Charging Infrastructure Planning Problems: A Comprehensive Review
}

\author{
Sanchari Deb
}

Citation: Deb, S. Machine Learning for Solving Charging Infrastructure Planning Problems: A

Comprehensive Review. Energies 2021, 14, 7833. https://doi.org/ $10.3390 /$ en14237833

Academic Editors: Om P. Malik, Abdulrahman Khalaf Al-Ali and Jaroslaw Krzywanski

Received: 29 July 2021

Accepted: 22 September 2021

Published: 23 November 2021

Publisher's Note: MDPI stays neutral with regard to jurisdictional claims in published maps and institutional affiliations.

Copyright: (C) 2021 by the author. Licensee MDPI, Basel, Switzerland. This article is an open access article distributed under the terms and conditions of the Creative Commons Attribution (CC BY) license (https:// creativecommons.org/licenses/by/ $4.0 /)$.

\author{
School of Engineering, University of Warwick, Coventry CV4 7AL, UK; sancharideb@yahoo.co.in
}

\begin{abstract}
As a result of environmental pollution and the ever-growing demand for energy, there has been a shift from conventional vehicles towards electric vehicles (EVs). Public acceptance of EVs and their large-scale deployment raises requires a fully operational charging infrastructure. Charging infrastructure planning is an intricate process involving various activities, such as charging station placement, charging demand prediction, and charging scheduling. This planning process involves interactions between power distribution and the road network. The advent of machine learning has made data-driven approaches a viable means for solving charging infrastructure planning problems. Consequently, researchers have started using machine learning techniques to solve the aforementioned problems associated with charging infrastructure planning. This work aims to provide a comprehensive review of the machine learning applications used to solve charging infrastructure planning problems. Furthermore, three case studies on charging station placement and charging demand prediction are presented. This paper is an extension of: Deb, S. (2021, June). Machine Learning for Solving Charging Infrastructure Planning: A Comprehensive Review. In the 2021 5th International Conference on Smart Grid and Smart Cities (ICSGSC) (pp. 16-22). IEEE. I would like to confirm that the paper has been extended by more than $50 \%$.
\end{abstract}

Keywords: charging; electric vehicle; machine learning; review

\section{Introduction}

Global energy consumption is increasing at an alarming rate, and the transportation sector is one of the largest consumers [1]. It was found that, in 2019, in the US, approximately $28 \%$ of the net energy consumption was involved in moving people and goods [2]. Furthermore, it was reported that the transport sector is one of the major agents of air pollution [3-5]. The paradigm shift from internal combustion engine (ICE)-driven vehicles to EVs is a viable way to mitigate the serious concerns regarding the energy crisis and air pollution. The large-scale adoption of EVs requires fully operational charging infrastructure. Charging infrastructure planning involves interactions between both the road and power distribution network. Charger placement at weak points in the power distribution network and uncoordinated charging can result in voltage instability, increased power losses, harmonic distortions, and degraded reliability indices [6-12]. Furthermore, charging infrastructure planning must also take into account the convenience of EV drivers, for example, the accessibility of the charging stations, and the waiting time in the charging stations [13]. Moreover, smart coordinated charging is preferred over uncoordinated charging to tackle the detrimental impact of EV charging on the grid [14]. Charging infrastructure planning is a multifaceted problem involving a number of decision variables, objective functions, and constraints. Researchers have used heuristics [15,16], metaheuristics [17], machine learning [18], and game theory $[19,20]$ for solving these problems.

In recent years, the advent of machine learning has made data-driven approaches popular for solving charging infrastructure planning problems. Consequently, researchers started using machine learning techniques to solve the problems associated with charging infrastructure planning, such as charging station placement, charging demand prediction, 
and charging scheduling. This work aims to provide a comprehensive review of machine learning applications for solving charging infrastructure planning problems. Table 1 lists prominent studies that meticulously review different aspects of charging infrastructure planning. From Table 1, it can be seen that researchers have reviewed various aspects of emobility, such as charging station placement, drivers of EV adoption, policies for promoting EVs, charging technologies, and charge scheduling. However, there is lack of comprehensive reviews focused on machine learning applications for solving charging infrastructure planning problems. Hence, this work aims to provide a comprehensive review of the machine learning applications used for solving different aspects of charging infrastructure planning, such as placement, charging demand prediction, and charging scheduling. Furthermore, case studies on charging infrastructure planning are also presented in this work. However, this paper contains more detailed descriptions of machine learning algorithms, more quantitative analyses of the reported literature, and three case studies on charging infrastructure planning. The main contributions of this work as compared to the reviews reported in Table 1 are as follows:

- A comprehensive review of the applications of machine learning algorithms for charging infrastructure planning;

- Qualitative and quantitative analyses of the reported literature;

- Recommendations regarding the suitability of machine learning algorithms for solving charging infrastructure planning problems;

- Case studies on charging hotspot identification and charging demand prediction.

Table 1. Reviews of charging infrastructure planning.

\begin{tabular}{|c|c|c|c|c|}
\hline Ref & Author & Journal/Conference & Year & Diligence \\
\hline [21] & Hardman et al. & $\begin{array}{l}\text { Transportation } \\
\text { Research Part D: } \\
\text { Transport and } \\
\text { Environment }\end{array}$ & 2018 & $\begin{array}{l}\text { Review of consumer preferences towards } \\
\text { and interactions with the EV charging } \\
\text { infrastructure. }\end{array}$ \\
\hline [22] & Pagany et al. & $\begin{array}{c}\text { International Journal } \\
\text { of Sustainable } \\
\text { Transportation }\end{array}$ & 2019 & $\begin{array}{l}\text { Review of spatial localization } \\
\text { methodologies for the electric vehicle } \\
\text { charging infrastructure. }\end{array}$ \\
\hline [23] & Zhang et al. & $\begin{array}{l}\text { Renewable and } \\
\text { Sustainable Energy } \\
\text { Reviews }\end{array}$ & 2018 & $\begin{array}{l}\text { Review of the economics of charging } \\
\text { infrastructure planning. }\end{array}$ \\
\hline [24] & Khan et al. & Smart Science & 2018 & $\begin{array}{l}\text { Review of fast charging infrastructure for } \\
\text { EVs. }\end{array}$ \\
\hline [25] & Das et al. & $\begin{array}{l}\text { Renewable and } \\
\text { Sustainable Energy } \\
\text { Reviews }\end{array}$ & 2020 & $\begin{array}{l}\text { Review of EV charging standards and } \\
\text { grid impacts of EV charging. }\end{array}$ \\
\hline [26] & Ji et al. & $\begin{array}{l}\text { Renewable and } \\
\text { Sustainable Energy } \\
\text { Reviews }\end{array}$ & 2018 & $\begin{array}{l}\text { Review of policies, methodologies, and } \\
\text { challenges for charging infrastructure } \\
\text { deployment in China. }\end{array}$ \\
\hline [27] & Coffman et al. & Transport Reviews & 2017 & $\begin{array}{c}\text { Review of factors affecting the adoption of } \\
\text { EVs. }\end{array}$ \\
\hline [28] & Rahman et al. & $\begin{array}{l}\text { Renewable and } \\
\text { Sustainable Energy } \\
\text { Reviews }\end{array}$ & 2016 & $\begin{array}{l}\text { Review of recent trends in optimization } \\
\text { techniques for plug-in hybrid and electric } \\
\text { vehicle charging infrastructures. }\end{array}$ \\
\hline [29] & Yang et al. & $\begin{array}{l}\text { Journal of Cleaner } \\
\text { Production }\end{array}$ & 2018 & $\begin{array}{l}\text { Suggestion on tax policy for promoting } \\
\text { the PPP projects of the charging } \\
\text { infrastructure in China. }\end{array}$ \\
\hline [30] & Rietmann et al. & $\begin{array}{l}\text { Journal of Cleaner } \\
\text { Production }\end{array}$ & 2019 & $\begin{array}{c}\text { Review of worldwide policy measures to } \\
\text { promote e-mobility. }\end{array}$ \\
\hline [31] & Ahmad et al. & Smart Science & 2018 & $\begin{array}{l}\text { Review of electric vehicle charging } \\
\text { techniques and standards, and the } \\
\text { progression and evolution of EV } \\
\text { technologies in Germany. }\end{array}$ \\
\hline
\end{tabular}


Table 1. Cont.

\begin{tabular}{|c|c|c|c|c|}
\hline Ref & Author & Journal/Conference & Year & Diligence \\
\hline [32] & Gnann et al. & $\begin{array}{l}\text { Renewable and } \\
\text { Sustainable Energy } \\
\text { Reviews }\end{array}$ & 2018 & Review of the global EV diffusion model. \\
\hline [33] & Ding et al. & $\begin{array}{l}\text { IEEE transaction on } \\
\text { Industry } \\
\text { Applications }\end{array}$ & 2020 & $\begin{array}{l}\text { Review on approaches for EV charging } \\
\text { demand management. }\end{array}$ \\
\hline [34] & Zhang et al. & $\begin{array}{l}\text { Renewable and } \\
\text { Sustainable Energy } \\
\text { Reviews }\end{array}$ & 2017 & Review of EV policies in China. \\
\hline [35] & Youssef et al. & $\begin{array}{l}\text { Materials Science and } \\
\text { Engineering } \\
\text { Conference Series }\end{array}$ & 2018 & $\begin{array}{l}\text { Review of EV DC charging stations using } \\
\text { photovoltaic sources. }\end{array}$ \\
\hline [36] & Du et al. & $\begin{array}{l}\text { Applied Energy } \\
\text { Transportation }\end{array}$ & 2017 & Review of EV industrialization in China. \\
\hline [37] & Hardman & $\begin{array}{l}\text { Transportation } \\
\text { Research Part A: } \\
\text { Policy and Practice }\end{array}$ & 2019 & $\begin{array}{l}\text { Review of financial incentives for EV } \\
\text { adoption. }\end{array}$ \\
\hline [38] & García et al. & $\begin{array}{l}\text { Applied Soft } \\
\text { Computing }\end{array}$ & 2018 & $\begin{array}{l}\text { Review of metaheuristics for solving } \\
\text { charging scheduling problems. }\end{array}$ \\
\hline [39] & Zheng et al. & $\begin{array}{l}\text { Renewable and } \\
\text { Sustainable Energy } \\
\text { Reviews }\end{array}$ & 2019 & $\begin{array}{l}\text { Review of the power interaction mode, } \\
\text { scheduling methodology, and } \\
\text { mathematical foundation for EV } \\
\text { integration with the power grid. }\end{array}$ \\
\hline [40] & Jawad et al. & Energies & 2020 & $\begin{array}{c}\text { Review of the current scenario of EV } \\
\text { charging service planning and operation } \\
\text { considering transport and the power } \\
\text { network. }\end{array}$ \\
\hline [41] & Solanke et al. & $\begin{array}{l}\text { Journal of Energy } \\
\text { Storage } \\
\text { Transportation }\end{array}$ & 2020 & $\begin{array}{c}\text { Review of strategic charging-discharging } \\
\text { control of grid-connected electric vehicles. } \\
\text { Review of EVs charging from the }\end{array}$ \\
\hline [42] & Amjad et al. & $\begin{array}{l}\text { Research Part D: } \\
\text { Transport and } \\
\text { Environment }\end{array}$ & 2018 & $\begin{array}{l}\text { perspective of energy optimization, } \\
\text { optimization approaches, and charging } \\
\text { techniques. }\end{array}$ \\
\hline [43] & Limmer & Energies & 2019 & $\begin{array}{c}\text { Review of dynamic pricing for EVs in } \\
\text { charging stations. }\end{array}$ \\
\hline [44] & Ahmadi et al. & $\begin{array}{l}\text { IET Electrical Systems } \\
\text { in Transportation }\end{array}$ & 2019 & $\begin{array}{l}\text { Review of power quality improvement in } \\
\text { smart grids by EVs. }\end{array}$ \\
\hline [45] & Ma & Energies & 2019 & $\begin{array}{l}\text { Review of planning of grid-connected } \\
\text { charging stations. }\end{array}$ \\
\hline [46] & Jia et al. & $\begin{array}{l}\text { Control Theory and } \\
\text { Technology }\end{array}$ & 2020 & $\begin{array}{c}\text { Review of charging behavior of data, } \\
\text { model, and control in EV charging } \\
\text { stations. }\end{array}$ \\
\hline$[47]$ & Panchal et al. & $\begin{array}{l}\text { Engineering Science } \\
\text { and Technology }\end{array}$ & 2018 & $\begin{array}{l}\text { Review of static and dynamic wireless } \\
\text { electric vehicle charging systems. }\end{array}$ \\
\hline [48] & Khan et al. & $\begin{array}{l}\text { Smart Science } \\
\text { Transportation and }\end{array}$ & 2018 & Review of solar EV charging stations. \\
\hline [49] & $\begin{array}{l}\text { Triviño-Cabrera } \\
\text { et al. }\end{array}$ & $\begin{array}{c}\text { Power Grid in Smart } \\
\text { Cities: } \\
\text { Communication } \\
\text { Networks and } \\
\text { Services }\end{array}$ & 2018 & $\begin{array}{c}\text { Review of wireless charging for smart } \\
\text { cities. }\end{array}$ \\
\hline [50] & Khan et al. & Smart Science & 2018 & $\begin{array}{c}\text { Review of Level } 2 \text { charging systems for } \\
\text { EVs. }\end{array}$ \\
\hline
\end{tabular}

\section{Overview of Charging Infrastructure Planning}

Charging infrastructure planning is a prerequisite for the large-scale adoption of EVs. The different activities associated with charging infrastructure planning are shown in Figure 1. Charging demand prediction involves the prediction of the demand of charging services at different times of the day and in different locations. Charging station placement 
is a typical planning problem centered on the optimal allocation and sizing of charging stations, which takes into consideration the economic factors, the operating parameters of the distribution network, and EV drivers' convenience. Charger utilization computation involves computing how much a charger is utilized or how many charging events a charger has served. Charging scheduling involves managing the charging activities based on the charging demand and load profile, while keeping in mind that the power grid must not be overloaded.

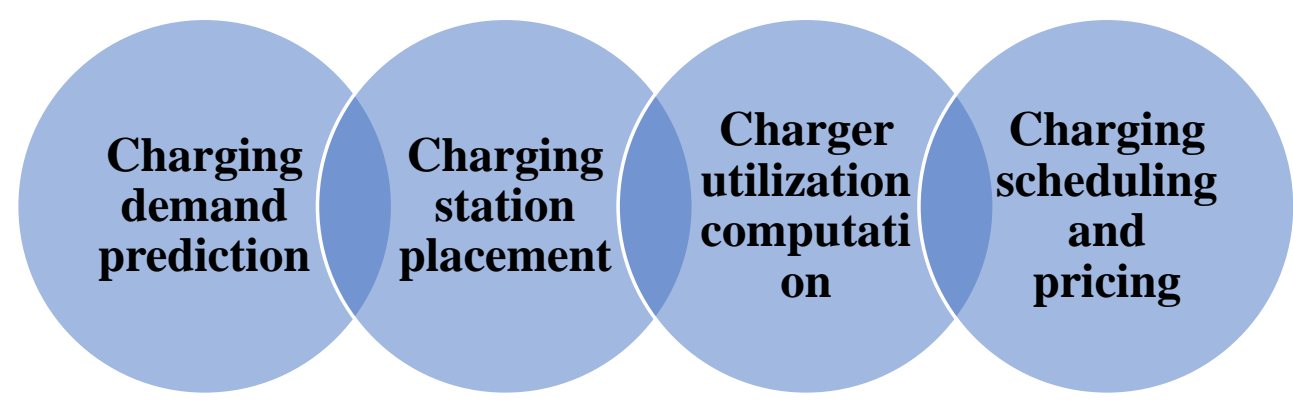

Figure 1. An overview of charging infrastructure planning.

\section{Machine Learning Techniques}

In machine learning, the computer learns from previous experience without any explicit programming [51]. In this context, experience refers to the dataset that the algorithm uses to train itself [52]. With time and learning experience, the models can accurately predict trends, thereby providing predictive analysis [51]. Typically, machine learning algorithms are categorized into supervised and unsupervised learning algorithms $[51,53,54]$. Furthermore, depending on the type of variable, the problems that machine learning algorithms approach can be divided into regression problems and the classification problems [51]. If the response variable is continuous, it is called a regression problem [51]; if the response variable is categorical, it is called a classification problem [51]. In the context of charging infrastructure planning, charging demand prediction is a regression problem, as the response variable is continuous. On the other hand, the identification of charging hotspots is a classification problem because the response variable is categorical.

Data partitioning in machine learning is the division of all data available into two or three nonoverlapping sets: the training set, the validation set, and the test set. The parameters of the model were fitted to the available data, and the model demonstrated high prediction accuracy on these data. Partitioning can be performed by different techniques, such as harsh partitioning, list partitioning, and composite partitioning [18].

The classification of machine learning algorithms is shown in Figure 2. Detailed descriptions of these groups are provided in the subsequent subsections.

\subsection{Supervised Learning}

As the name indicates, supervised machine learning models are trained by labeled datasets $[51,55,56]$. The dataset contains the input variable and target variable. Model learning is iterative in nature and works by mapping between the input and target output assisted by optimization [51]. As shown in Figure 2, supervised learning can be divided into five types. In the linear regression model, there is a linear relationship between the input variable and the target variable [51]. Linear regression can be used for regression problems and for linearly separable datasets [54]. Decision trees can be used for both regression and classification problems [54]. Decision trees separate complex decisions into simpler decisions using split points $[54,57,58]$. In the random forest technique, several decision trees are aggregated for the purpose of prediction $[59,60]$. A support vector machine (SVM) is mainly used for classification problems, but can also be utilized for regression problems [61,62]. An SVM separates the classes with the best hyperplane, which maximizes the marginal difference between the classes $[18,62]$. The training time for an 
SVM is long, and therefore, it is not suitable for large datasets [61,62]. K-nearest neighbors $(\mathrm{KNN})$ can be used for both regression and classification problems $[18,63,64]$. However, it is mostly used for classification problems [18]. KNN does not require a dedicated training phase and it is associated with a lazy learning phase $[18,63,64]$.

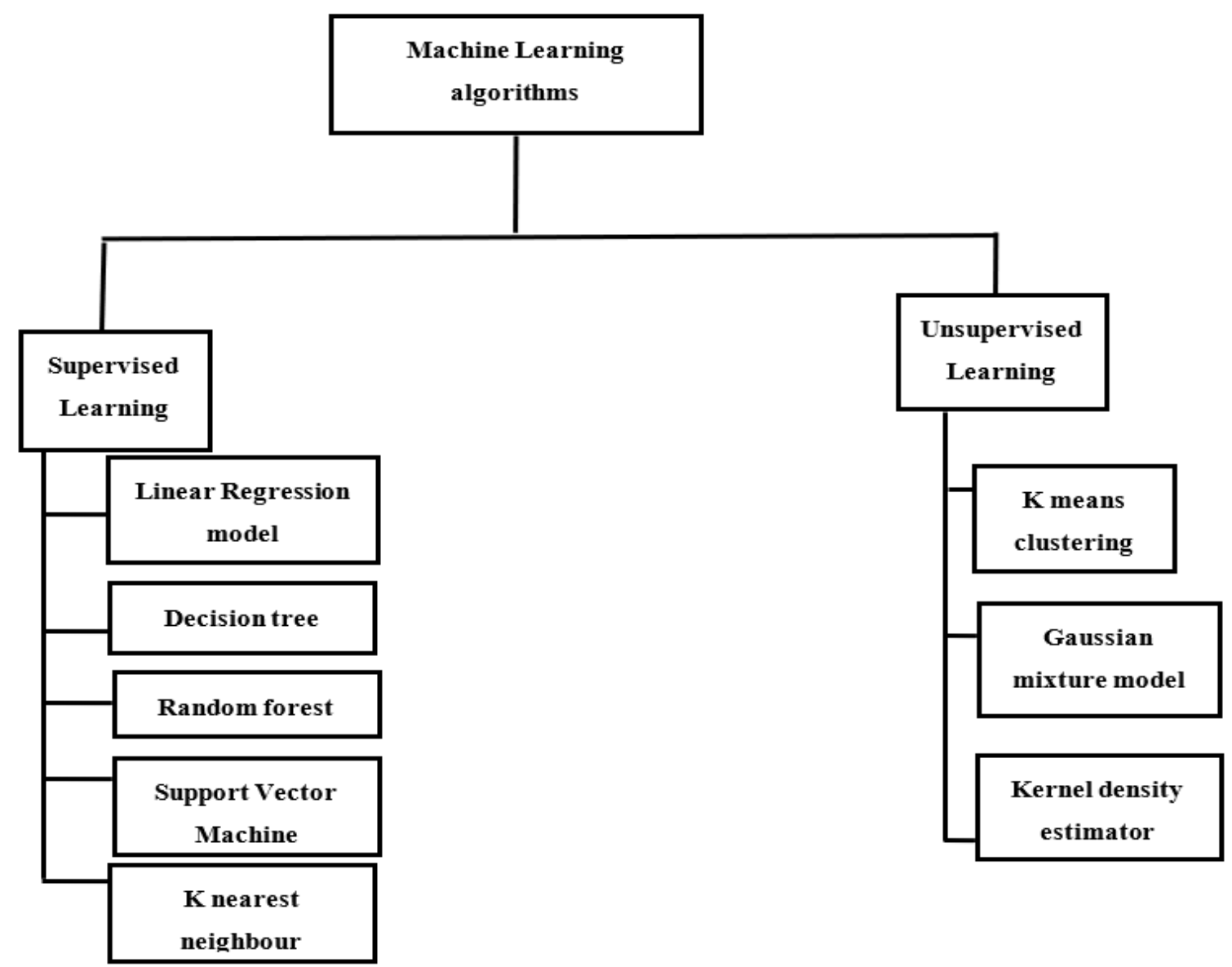

Figure 2. Classification of machine learning algorithms.

There is also another class known as semi-supervised learning. Semi-supervised learning is an innovative approach to machine learning that combines a small amount of labeled data and a large amount of unlabeled data during training. Semi-supervised learning falls between unsupervised learning (with no labeled training data) and supervised learning (with only labeled training data) [52].

\subsection{Unsupervised Learning}

In the case of unsupervised learning, the training dataset comprises the input variable only $[18,65,66]$. The key goal of this model is to find patterns within the dataset using clustering $[18,65,66]$. The subdivisions of unsupervised learning are as illustrated in Figure 2. In $\mathrm{k}$ clustering, individual datapoints form $\mathrm{k}$ clusters, wherein each and every point is assigned to $\mathrm{k}$ center points at the beginning in a random fashion [18,67], and later datapoints are assigned to the nearest centers based on new datapoint calculations. The Gaussian mixture model (GMM) is a probabilistic learning model that has the capacity to represent subpopulations of normal distribution by considering multiple normal distributions of the dataset in use [18]. The kernel density estimator (KDE) is used in the case of a nonparametric probability density function [18].

\section{Performances of Machine Learning Algorithms}

The performances of different machine learning algorithms can be compared on the basis of some metrices. For regression models, root mean square error (RMSE), mean 
absolute error $(M A E)$, and mean absolute percentage error (MAPE) are some of the metrices for performance evaluation [18].

Equations (1)-(3) represent these indices mathematically.

$$
\begin{gathered}
R M S E=\sqrt{\frac{\sum_{i=1}^{n}\left(y_{i}-y_{i}^{\prime}\right)}{n}} \\
M A E=\frac{1}{n} \sum_{i=1}^{n} y_{i}-y_{i}^{\prime} \\
M A P E=\frac{1}{n} \sum_{i=1}^{n}\left[\frac{y_{i}-y_{i}^{\prime}}{y_{i}^{\prime}}\right] \times 100
\end{gathered}
$$

Ideally, the difference between the predicted value $y_{i}^{\prime}$, and the target value $y_{i}$, should be small.

For the classification problem, the evaluation metrices are accuracy, precision, and $F 1$ score [18], as follows:

$$
\begin{gathered}
\text { Accuracy }=\frac{T P+T N}{T P+T N+F P+F N} \\
\text { Precision }=\frac{T P}{T P+F P} \\
F 1 \text { score }=\frac{2 \times \text { Precision } \times T P R}{\text { Precision }+T P R}
\end{gathered}
$$

A true positive (TP) represents a case in which the predicted positive class value and the real value belong to the positive class. Moreover, a true negative (TN) represents a case in which the predicted negative class value and the real value belong to the negative class. False positives $(F P)$ are cases in which the model falsely predicts the positive class for actual values belonging to the negative class. False negatives $(F N)$ are cases in which the model falsely predicts the negative class for actual values belonging to the positive class.

\section{Machine Learning for Charging Infrastructure Planning}

Applications of machine learning techniques for solving different charging infrastructure planning problems are shown in Figure 1.

\subsection{Machine Learning for Charging Station Placement}

The charging station problem involves determining the locations and sizes of chargers. In [68], the authors provided an optimal wireless charging station placement scheme for electric trams by applying an algorithm that hybridizes the genetic algorithm (GA) and reinforcement learning (RL). The integration of GA with reinforcement learning improved the performance of GA by preventing it from becoming stuck in local optima. The superior performance of the hybrid GA RL algorithm as compared with the standalone algorithms is illustrated in Table 2.

Table 2. A performance comparison of GA RL with standalone GA and RL algorithms [68].

\begin{tabular}{cccc}
\hline Parameter & GA & RL & GA + RL \\
\hline Investment cost $(\$)$ & 106.230 & 104.561 & 103.891 \\
Battery capacity $(\mathrm{kWh})$ & 15.06 & 13.14 & 12.60 \\
\hline
\end{tabular}

In [69], the authors provided a novel scheme for placing new charging stations that utilizes the maximization utilization rate of chargers as the objective function. The problem was solved by hierarchal clustering [70]. In [71], the authors categorized charging stations as top ranked and bottom ranked using the linear regression model and decision trees. The simulation results established the superiority of the linear regression model over decision trees. In [72], a cellular automaton agent-based model was proposed to study different EV deployment scenarios. 


\subsection{Machine Learning for Charging Demand Prediction}

Accurately predicting the charging load is crucial for charging infrastructure planning and the large-scale adoption of EVs. In [73], the authors presented a novel scheme for predicting the aggregated load demand of buildings in the presence of EVs that utilizes a methodology based on feature selection and an enhanced SVM. In [74], the authors predicted the charging load of the UCLA campus by applying a modified pattern sequencebased technique. In [75], the authors used a deep learning approach to estimate multiscale EV charging demand. Moreover, in [76,77], an enhanced deep learning-based approach was used for charging load prediction. In [78], the authors used a hybrid ant lion algorithm and deep learning for charging demand prediction. In [79], the authors proposed a hybrid KDE using both Gaussian and diffusion-based KDE (GKDE and DKDE) to predict the stay duration and charging demand of EVs. In [80], authors employed a generalized regression neural network (GRNN) model to predict the charging load. In [81], the authors predicted the charging demands of electric bus charging stations using an SVM and the wolf pack algorithm. In [82], the authors compared the performances of different deep learning approaches as applied to the charging demand prediction problem, and concluded that the long short-term memory (LSTM) method performed best, as it reduced the forecasting error by over $30 \%$. In [83], the authors used a regression model to predict the charging load. In [84], the authors compared the time series approach with machine learning techniques, such as the random forest technique and the regression model, as applied to the charging demand prediction problem. The simulation results established the superiority of machine learning techniques over the time series approach. In [85], the authors used ensemble learning to predict household EV charging demand. Ensemble learning is a machine learning technique that leans by evaluating the results from different machine learning models. In the aforementioned work, the ensemble learning model was based on the results of the random forest, gradient boosting, adaptive boosting, and regression techniques. In [86], the authors used the k-nearest neighbors method for charging demand prediction. In [87], the authors applied a neural network to predict the charger occupancy for an EV charging station in an urban area.

\subsection{Machine Learning for Charging Scheduling}

The management of charging activities at charging stations is important to avoid sudden increases in the peak load demand. In [88], the authors considered the operational benefit of EVs by focusing on vehicle-to-grid (V2G) technology and scheduled EV charging at charging stations using reinforcement learning. In [89], the authors proposed a demand response method for long-term charging cost reduction and provided a charging schedule for EVs. The solution was based on reinforcement learning. In [90], the authors proposed a constrained EV charge scheduling strategy and utilized reinforcement learning for this. In [91], the authors formulated charging scheduling as a NP-hard problem and found a solution using reinforcement learning. In [90], the authors proposed an artificial neural network (ANN) for solving charging scheduling and suggested adopting a smart pricing strategy at charging stations. In [92], the authors identified the best charging time for EVs in a fast-charging station integrated with a smart grid using the Q-learning method. In [93,94], the authors solved the charging scheduling problem using reinforcement learning. In $[95,96]$, the authors used multiagent reinforcement learning for charging scheduling and proposed a dynamic pricing strategy. In [97], the authors proposed a reinforcement learning-based approach for optimizing the charging scheduling and pricing strategies of a public EV charging station. In [98], the authors used reinforcement learning to regulate charging scheduling for electric buses in a charging station in a smart grid environment.

\subsection{Machine Learning for Charger Utilization Prediction}

Estimating the charger utilization rate is essential for the expansion of the charging infrastructure. In [99], the authors predicted EV charging station usage using an ANN. In [100], the authors used the linear regression model to compute the charger idle time 
for a dataset in the Netherlands. In [101], the authors used the linear regression model to predict the charger utilization rate, assuming a nonlinear charging profile.

\section{Literature Review Summary}

A summary of the research reported in the previous section is presented in Table 3. Furthermore, a quantitative analysis of the reported literature is presented in Figure 3. From Figure 3 , it is clear that machine learning techniques can be successfully applied to charging demand prediction problems.

Table 3. Summary of the research concerning the use of machine learning for charging infrastructure planning.

\begin{tabular}{|c|c|c|c|c|c|}
\hline Ref & Author & Journal & Year & Problem & Technique \\
\hline [68] & Ko & $\begin{array}{l}\text { Computers and } \\
\text { Industrial } \\
\text { Engineering }\end{array}$ & 2019 & $\begin{array}{l}\text { Charging station } \\
\text { placement }\end{array}$ & Hybrid GA RL \\
\hline [69] & Pevec et al. & $\begin{array}{l}\text { International Journal } \\
\text { of Energy Research }\end{array}$ & 2018 & $\begin{array}{l}\text { Charging station } \\
\text { placement. }\end{array}$ & Hierarchal clustering \\
\hline$[70]$ & Cohen-Addad et al. & $\begin{array}{l}\text { Journal of the ACM } \\
\text { (JACM) }\end{array}$ & 2019 & $\begin{array}{l}\text { Charging station } \\
\text { placement }\end{array}$ & $\begin{array}{l}\text { Linear regression } \\
\text { model and decision } \\
\text { trees }\end{array}$ \\
\hline [71] & Straka & Preprint & 2018 & $\begin{array}{l}\text { Charging demand } \\
\text { prediction }\end{array}$ & SVM \\
\hline [73] & Duan et al. & $\begin{array}{l}\text { Sustainable Cities } \\
\text { and Society } \\
2014 \text { IEEE }\end{array}$ & 2014 & $\begin{array}{l}\text { Charging Demand } \\
\text { prediction }\end{array}$ & $\begin{array}{l}\text { Modified pattern } \\
\text { sequence }\end{array}$ \\
\hline [74] & Majidpour et al. & $\begin{array}{c}\text { International } \\
\text { Conference on Smart } \\
\text { Grid } \\
\text { Communications }\end{array}$ & 2019 & $\begin{array}{l}\text { Charging Demand } \\
\text { prediction }\end{array}$ & Deep learning \\
\hline [75] & Zhu et al. & $\begin{array}{l}\text { IEEE Innovative } \\
\text { Smart Grid } \\
\text { Technologies-Asia } \\
\text { (ISGT Asia) } \\
\text { 4th International }\end{array}$ & 2017 & $\begin{array}{l}\text { Charging Demand } \\
\text { prediction }\end{array}$ & Deep learning \\
\hline [76] & Li et al. & $\begin{array}{c}\text { Conference on } \\
\text { Information Science } \\
\text { and Control } \\
\text { Engineering (ICISCE) }\end{array}$ & 2019 & $\begin{array}{l}\text { Charging Demand } \\
\text { prediction }\end{array}$ & Deep learning \\
\hline [77] & Zhu et al. & Applied Science & 2018 & $\begin{array}{l}\text { Charging Demand } \\
\text { prediction }\end{array}$ & $\begin{array}{l}\text { Hybrid ant lion and } \\
\text { deep learning }\end{array}$ \\
\hline [78] & Li et al. & Energies & 2018 & $\begin{array}{l}\text { Charging Demand } \\
\text { prediction }\end{array}$ & Hybrid KDE \\
\hline [79] & Chung et al. & $\begin{array}{l}\text { IEEE International } \\
\text { Conference on } \\
\text { Probabilistic } \\
\text { Methods Applied to } \\
\text { Power Systems } \\
\text { (PMAPS) }\end{array}$ & 2020 & $\begin{array}{l}\text { Charging Demand } \\
\text { prediction }\end{array}$ & GRNN \\
\hline [80] & Mansour et al. & Electronics & 2018 & $\begin{array}{l}\text { Charging Demand } \\
\text { prediction }\end{array}$ & SVM \\
\hline [81] & Zhang & Energies & 2019 & $\begin{array}{l}\text { Charging Demand } \\
\text { prediction }\end{array}$ & Deep learning \\
\hline [82] & Zhu et al. & Energies & 2020 & $\begin{array}{l}\text { Charging Demand } \\
\text { prediction }\end{array}$ & Regression model \\
\hline [83] & Almaghrebi et al. & Energies & 2019 & $\begin{array}{l}\text { Charging Demand } \\
\text { prediction }\end{array}$ & $\begin{array}{l}\text { Random forest and } \\
\text { regression model }\end{array}$ \\
\hline [84] & Buzna et al. & $\begin{array}{l}\text { 1st International } \\
\text { Conference on } \\
\text { Energy Transition in } \\
\text { the Mediterranean } \\
\text { Area (SyNERGY } \\
\text { MED) }\end{array}$ & 2018 & $\begin{array}{l}\text { Charging Demand } \\
\text { prediction }\end{array}$ & Ensemble learning \\
\hline [85] & Ai eta al. & $\begin{array}{l}\text { IEEE International } \\
\text { Conference on } \\
\text { Energy Internet } \\
\text { (ICEI) }\end{array}$ & 2014 & $\begin{array}{c}\text { Charging Demand } \\
\text { prediction }\end{array}$ & KNN \\
\hline
\end{tabular}


Table 3. Cont.

\begin{tabular}{|c|c|c|c|c|c|}
\hline Ref & Author & Journal & Year & Problem & Technique \\
\hline$[86]$ & Majidpour et al. & $\begin{array}{c}\text { IEEE Transactions on Industrial } \\
\text { Informatics }\end{array}$ & 2019 & $\begin{array}{l}\text { Charging Demand } \\
\text { prediction }\end{array}$ & $\begin{array}{l}\text { Reinforcement } \\
\text { learning }\end{array}$ \\
\hline [87] & Dang et al. & $\begin{array}{c}\text { IEEE Transportation } \\
\text { Electrification Conference and } \\
\text { Expo (ITEC) }\end{array}$ & 2020 & $\begin{array}{l}\text { Charging Demand } \\
\text { prediction }\end{array}$ & $\begin{array}{l}\text { Reinforcement } \\
\text { learning }\end{array}$ \\
\hline$[88]$ & Wang et al. & $\begin{array}{l}\text { IEEE Transactions on Vehicular } \\
\text { Technology }\end{array}$ & 2019 & Charging scheduling & $\begin{array}{l}\text { Reinforcement } \\
\text { learning }\end{array}$ \\
\hline [89] & Li et al. & IEEE Transactions on Smart Grid & 2019 & Charging scheduling & $\begin{array}{l}\text { Reinforcement } \\
\text { learning }\end{array}$ \\
\hline$[90]$ & Zhang et al. & $\begin{array}{l}\text { IEEE Transactions on Intelligent } \\
\text { Transportation Systems }\end{array}$ & 2020 & Charging scheduling & ANN \\
\hline [91] & Dang et al. & $\begin{array}{c}\text { IEEE Transportation } \\
\text { Electrification Conference and } \\
\text { Expo (ITEC) }\end{array}$ & 2018 & Charging scheduling & $\begin{array}{l}\text { Reinforcement } \\
\text { learning }\end{array}$ \\
\hline [92] & Sharbaaf et al. & $\begin{array}{l}2018 \text { Electrical Power Distribution } \\
\text { Conference (EPDC) }\end{array}$ & 2018 & Charging scheduling & $\begin{array}{l}\text { Reinforcement } \\
\text { learning }\end{array}$ \\
\hline$[93]$ & Liang et al. & IEEE Transactions on Smart Grid & 2018 & Charging scheduling & $\begin{array}{l}\text { Reinforcement } \\
\text { learning }\end{array}$ \\
\hline$[94]$ & Wan et al. & IEEE Transactions on Smart Grid & 2020 & Charging scheduling & $\begin{array}{l}\text { Reinforcement } \\
\text { learning }\end{array}$ \\
\hline [95] & Han et al. & $\begin{array}{l}\text { IEEE Global Communications } \\
\text { Conference (GLOBECOM) }\end{array}$ & 2019 & Charging scheduling & $\begin{array}{l}\text { Reinforcement } \\
\text { learning }\end{array}$ \\
\hline [96] & Shin et al. & $\begin{array}{l}\text { IEEE Transaction on Industrial } \\
\text { Informatics }\end{array}$ & 2019 & Charging scheduling & $\begin{array}{l}\text { Reinforcement } \\
\text { learning }\end{array}$ \\
\hline [97] & Wang et al. & $\begin{array}{l}\text { IEEE Transaction on Industrial } \\
\text { Informatics }\end{array}$ & 2019 & Charging scheduling & $\begin{array}{l}\text { Reinforcement } \\
\text { learning }\end{array}$ \\
\hline [98] & Chen et al. & $\begin{array}{l}\text { IEEE Global Communications } \\
\text { Conference (GLOBECOM) }\end{array}$ & 2018 & Charger utilization & ANN \\
\hline [99] & $\begin{array}{l}\text { Ramachandran } \\
\text { et al. }\end{array}$ & Preprint & 2019 & Charger utilization & $\begin{array}{l}\text { Linear regression } \\
\text { model }\end{array}$ \\
\hline [100] & Lucas et al. & Energies & 2019 & Charger utilization & $\begin{array}{l}\text { Linear regression } \\
\text { model }\end{array}$ \\
\hline [101] & Frendo et al. & Energy and AI & 2021 & $\begin{array}{l}\text { Charging station } \\
\text { placement }\end{array}$ & Supervised learning \\
\hline [102] & Ma et al. & Preprint & 2021 & $\begin{array}{l}\text { Charging demand } \\
\text { prediction }\end{array}$ & ANN \\
\hline
\end{tabular}

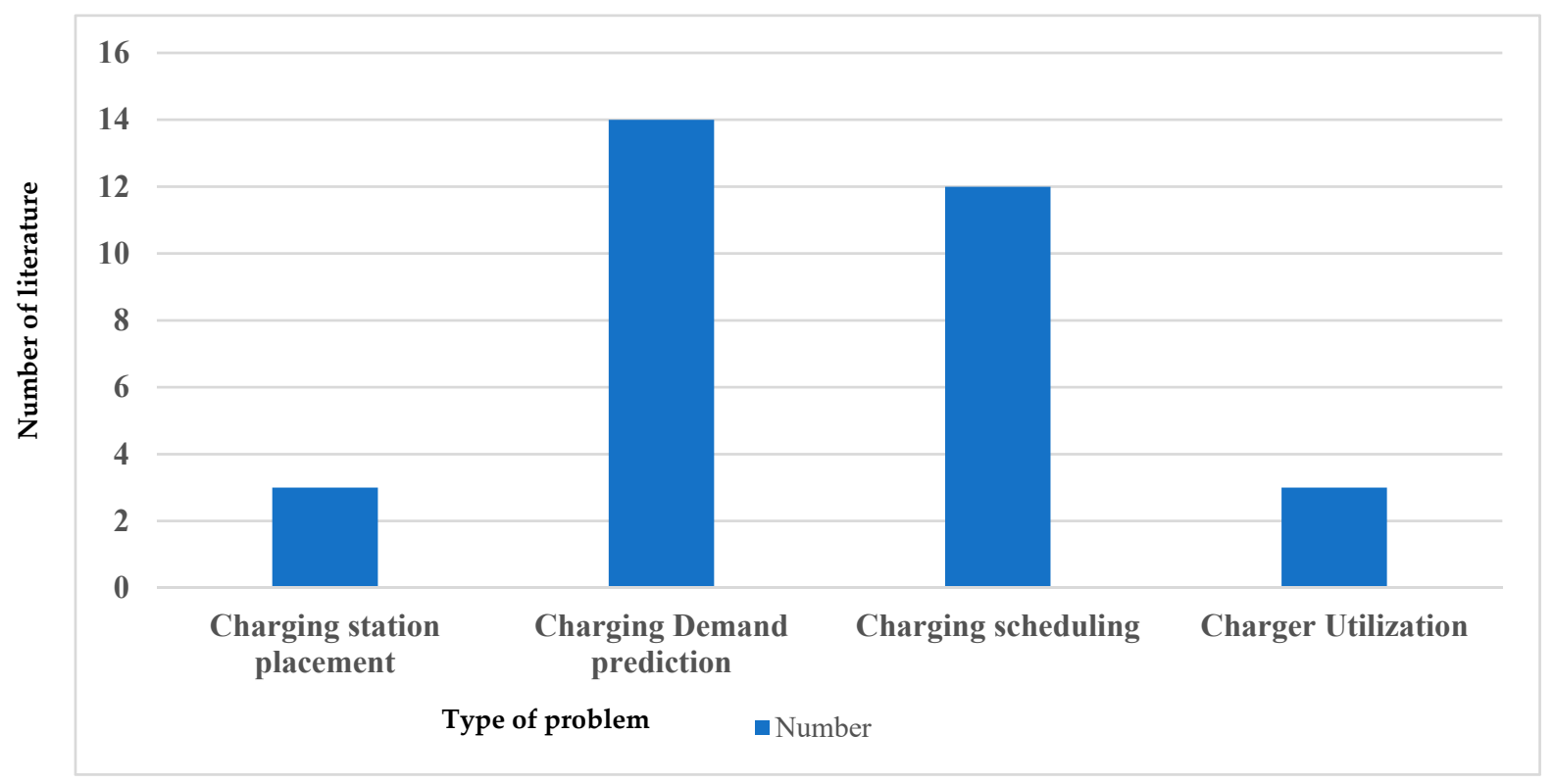

Figure 3. Quantitative analysis of the reported literature. 


\section{Case Studies}

\subsection{Home Charging Hotspot Prediction for Helsinki, Finland}

Charging hotspots are points with relatively high charging demand throughout the day. It is expected that, during the initial stages of EV deployment, the majority of charging activity will take place at home. Hence, identifying home charging hotspots is necessary. In this work, we identified home charging hotspots for the city of Helsinki. The charging behavior and schedule of EV drivers in Helsinki specifically concerning home charging was modeled using the Activity-Based Transport Model (ABTM) [103,104]. A data-driven approach was adopted to identify the charging hotspots. The output of the ABTM model was utilized as an input with which to evaluate the charging hotspots. In this scenario, it was considered that the EV drivers charged their vehicles at home at the end of their journeys. The data-driven approach used for the identification of home charging hotspots is shown in Figure 4. Moreover, the home charging hotspots computed using the methodology shown in Figure 4 are presented in Table 4.

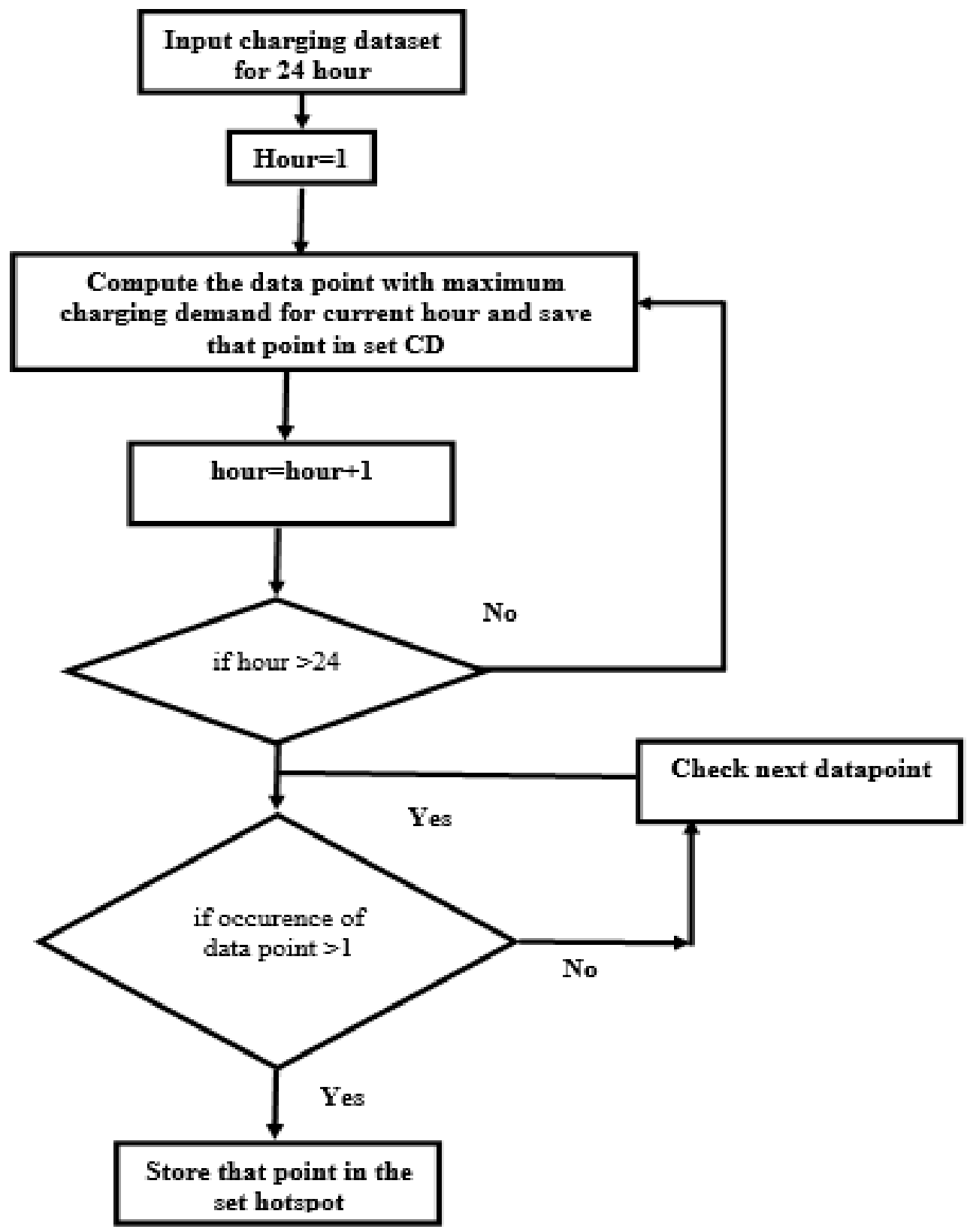

Figure 4. Flowchart for the computation of home charging hotspots [105]. 
Table 4. Home charging hotspots for Helsinki [105].

\begin{tabular}{ccccc}
\hline Latitude & Longitude & Location & Region & Pin \\
\hline 60.16088 & 24.92796 & Hietalahdenranta 14 & Helsinki & 00180 \\
60.17884 & 24.945945 & Säästöpankinranta 10 & Helsinki & 00530 \\
60.349377 & 25.05433 & Kuhankeittäjäntie 5 & Vantaa & 01450 \\
60.14246 & 24.640027 & Ristiniementie 5 & Espoo & 02320 \\
60.197788 & 24.92788 & Pasilankatu 8b & Helsinki & 00240 \\
\hline
\end{tabular}

\subsection{Commercial Charging Hotspot Prediction for Dundee City Council, United Kingdom}

In addition to home charging, commercial public charging stations will be required for the large-scale adoption of EVs. Therefore, the identification of commercial public charging hotspots is also essential. A data-driven methodology was used for the identification of charging hotspots for Dundee city council, as shown in Figure 5. The identified charging hotspots are presented in Table 5.

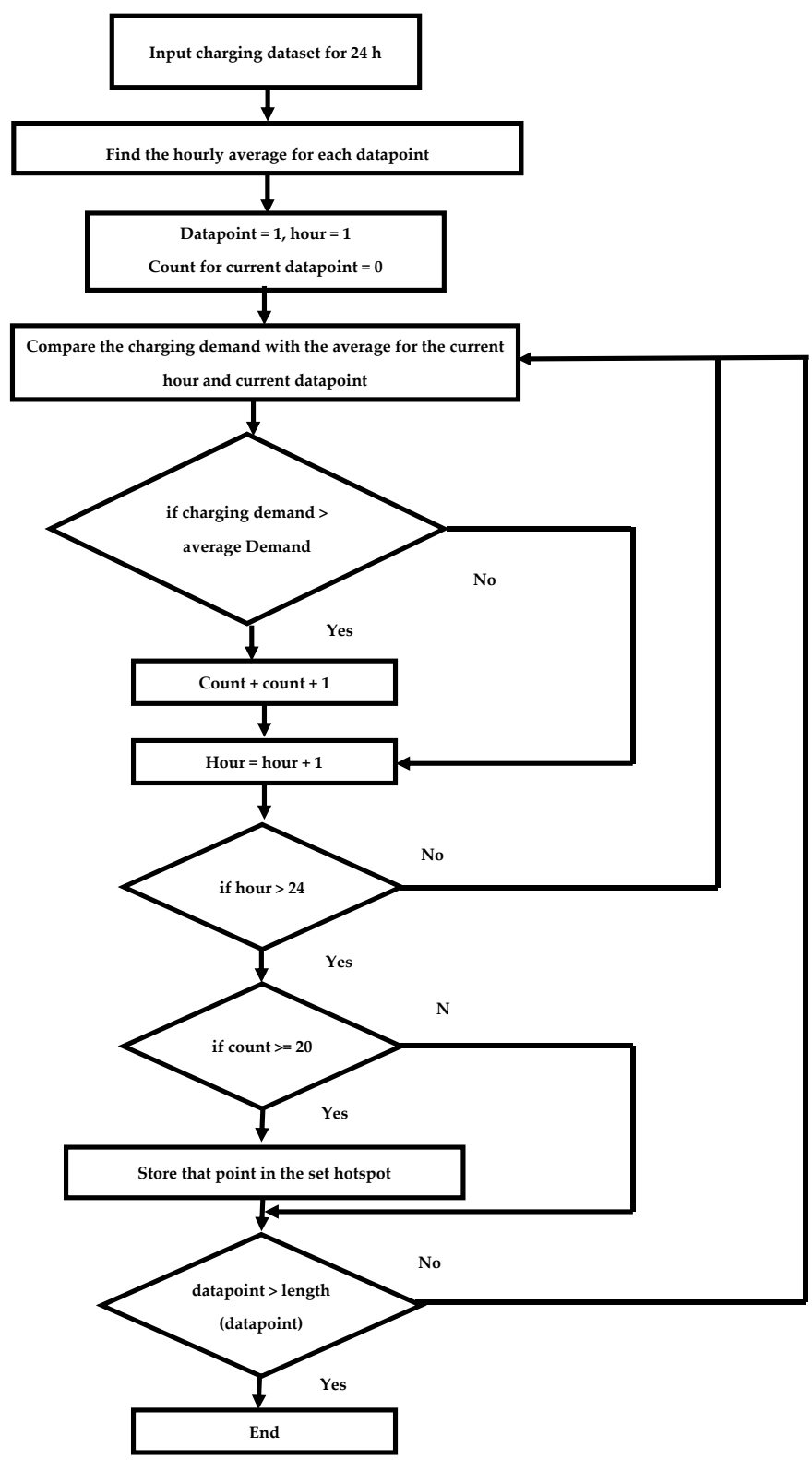

Figure 5. Flowchart for the computation of public commercial charging hotspots [105]. 
Table 5. Commercial public charging hotspots for Dundee city council.

\begin{tabular}{|c|c|c|c|}
\hline Latitude & Longitude & Location & Type \\
\hline 56.47296514 & -3.011192798 & Housing Office West & Slow \\
\hline 56.46983341 & -3.057191231 & Hillcrest Housing Association & Fast \\
\hline 56.48982926 & -2.917475296 & Whitfield Centre & Slow \\
\hline 56.46149716 & -2.96647828 & Gellatly Street Car Park & Fast \\
\hline 56.4821483 & -3.024697396 & Dundee Ice Arena & Fast \\
\hline 56.46999414 & -2.910300665 & Oranges \& Lemons & Slow \\
\hline 56.45682527 & -2.973600267 & Greenmarket Car Park & Fast \\
\hline 56.4575 & -2.9785 & Dundee University & Slow \\
\hline 56.45563168 & -3.024181427 & Dundee University Botanic Gardens & Slow \\
\hline 56.4725685 & -2.973004185 & Taxi Hub, Isla street & Slow and Fast \\
\hline 56.48588707 & -2.89249497 & Michelin Tyres & Fast \\
\hline 56.46779037 & -2.873580046 & Queen Street Car Park & Slow \\
\hline 56.47946054 & -2.90444341 & Douglas Community Centre & Slow \\
\hline 56.47796824 & -2.913471531 & Janet Brougham House & Slow \\
\hline 56.47016332 & -2.920663615 & Brington Place Sheltered Housing & Slow \\
\hline 56.47847573 & -2.94163689 & AutoecosseMitsibushi & Slow \\
\hline 56.48838239 & -3.014352526 & Ardler Complex & Slow \\
\hline 56.46543565 & -3.035060314 & Menziehill House & Slow \\
\hline 56.45677168 & -3.068633303 & James Hutton Institute & Slow \\
\hline 56.46553827 & -3.04197669 & Ninewells Car Park & Fast \\
\hline 56.46238032 & -3.016417028 & Royal Victoria Hospital & Fast \\
\hline 56.46826957 & -3.005973737 & Oakland Centre & Slow \\
\hline 56.47296831 & -3.002456461 & Marchbanks & Slow \\
\hline 56.46355616 & -2.962498196 & Olympia Multi-Storey Car Park & Slow \\
\hline 56.46297438 & -2.966068959 & Trades Lane & Fast \\
\hline 56.46024694 & -2.966793953 & Dock Street & Fast \\
\hline 56.4568153 & -2.977853701 & Perth Road & Fast \\
\hline 56.45907815 & -2.977267895 & South Tay Street & Fast \\
\hline
\end{tabular}

\subsection{Charging Demand Prediction for Helsinki, Finland}

Predicting the charging demand in advance will assist in the smart and effective management of the charging load. In this work, a case study on charging demand prediction using the random forest technique for e-buses and private EVs in Helsinki is presented. The RF model was validated for Leepavara, which is a commercial shopping hub in Espoo, Finland. The e-buses charging dataset was generated using the bus timetables available on the HSL website [106-108]. Moreover, the charging dataset for private EVs was generated using the Bayesian network (BN)-based approach [109-111] proposed in [112]. The congestion levels in the city, as recorded using the Tom application [113] and shown in Figure 6, and the typical traffic conditions in Leepavara, as shown in Figure 7, were also taken into account while generating the charging dataset for private EVs. The charging demand was predicted using the random forest technique. The target and predicted charging demands are shown in Figure 8.

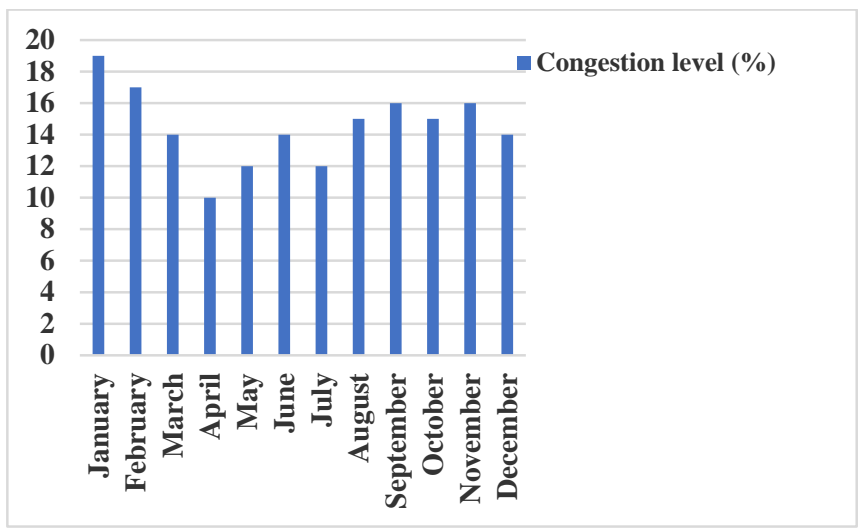

Figure 6. Congestion levels in Helsinki [113]. 


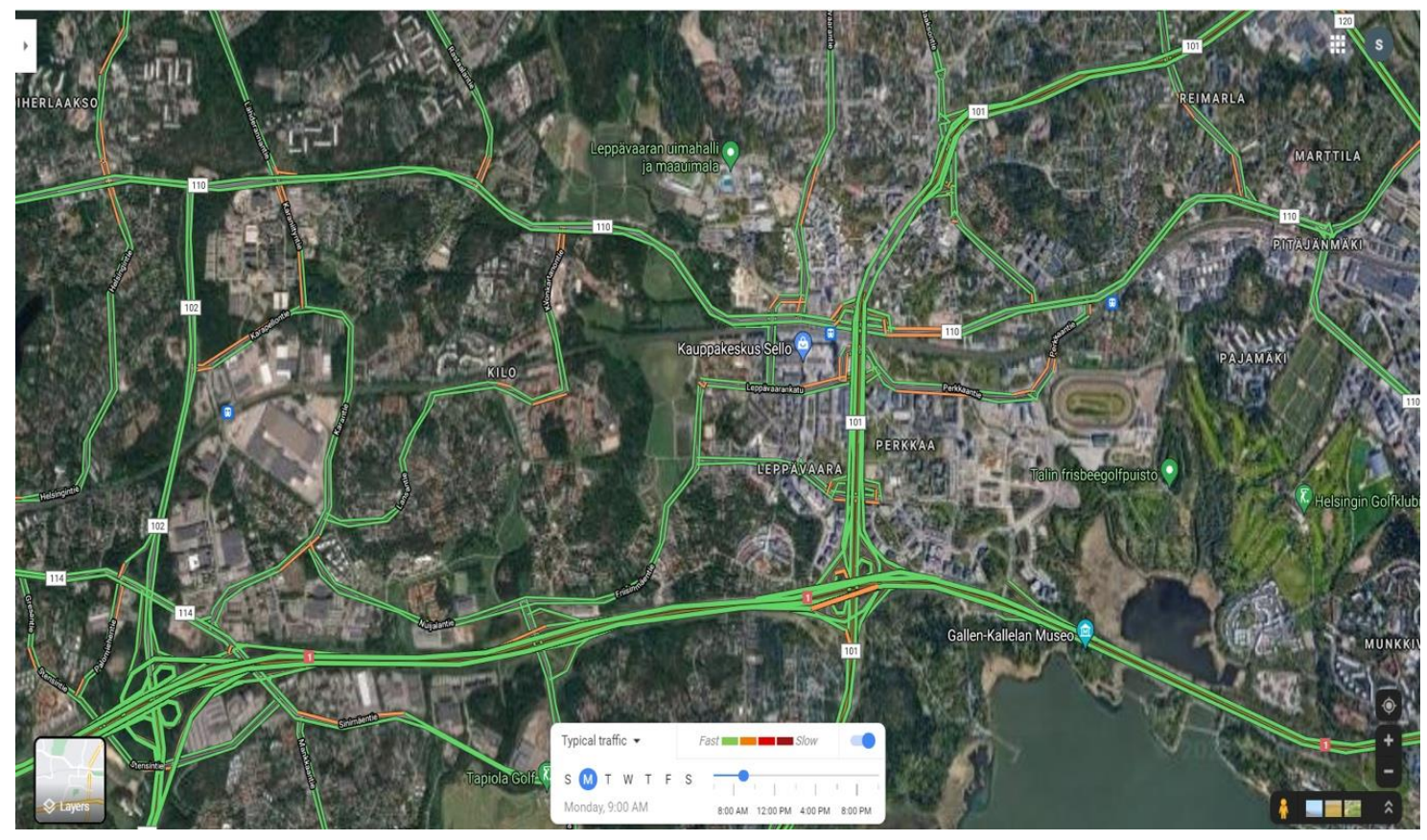

Figure 7. Typical Monday morning traffic in Leepavara (source: Google Maps).

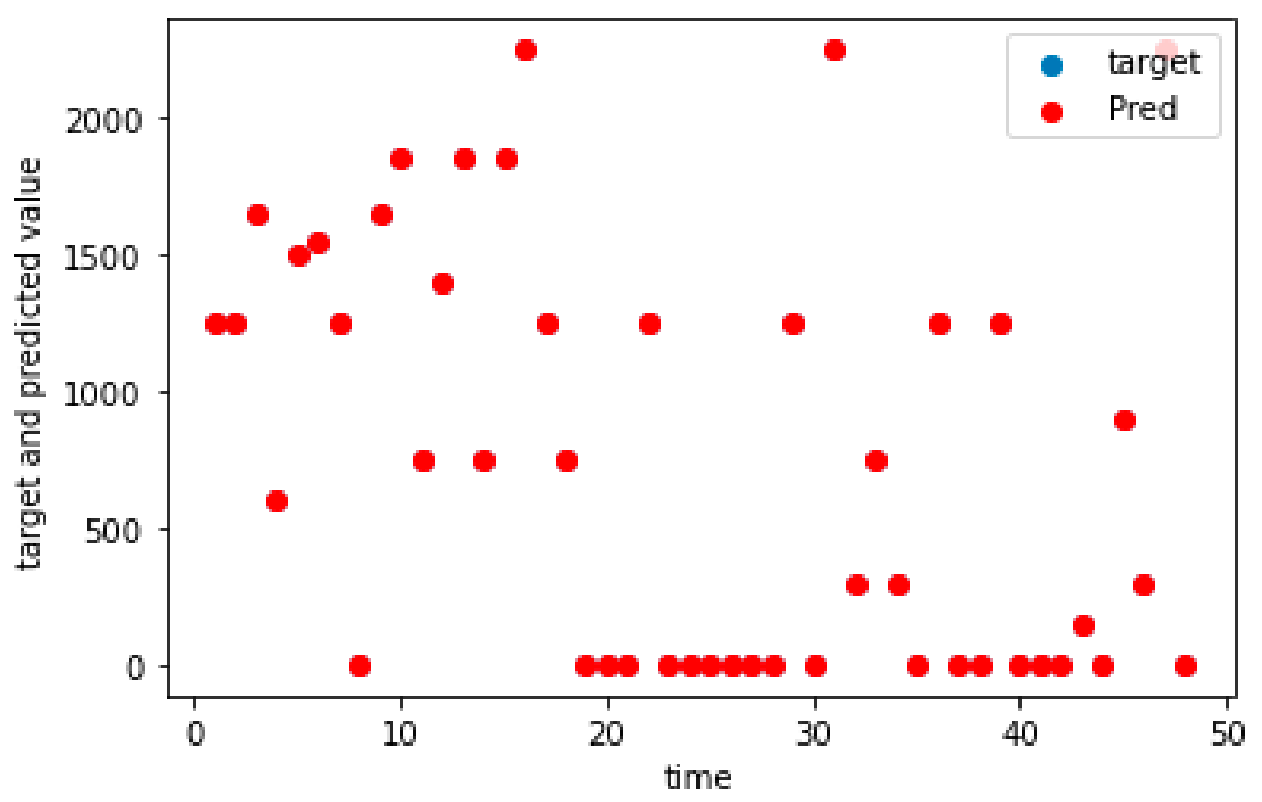

Figure 8. Target and predicted charging demand in $\mathrm{kW}$.

Note: In the above figure, red implies high traffic levels, amber implies moderate traffic levels, and green implies lower traffic levels.

\section{Discussions}

This work comprehensively reviews the applications of machine learning algorithms for solving charging infrastructure planning problems. An overview of charging infrastructure planning is also provided herein. Charging station placement, charging demand prediction, charger utilization computation, and charging scheduling and pricing are some of the activities involved in charging infrastructure planning. Dedicated chargers serve the scheduled EV operations, which can be derived from GTFS and fleet management (i.e., to provide the combined flow of EVs). Different machine learning algorithms, such as 
supervised learning, reinforcement learning, and ANN, are used extensively for solving these problems. Qualitative and quantitative analyses of the research in this arena are provided. It can be seen that machine learning algorithms can be successfully applied to charging demand prediction and charging scheduling. SVM, deep learning, and random forest techniques are extensively used in charging demand prediction. Moreover, reinforcement learning is widely used for solving the problem of charging scheduling. Three case studies focused on charging infrastructure planning are also provided in this work in order to provide real-world examples. The first case study was focused on identifying home charging hotspots in the city of Helsinki, Finland, using a data-driven methodology. One of the main contributions of the first case study is the realization that initial EV adopters will mostly rely on home charging. The second case study identified public charging hotspots for Dundee city council. The identification of charging hotspots in advance will help power grid operators check whether grid reinforcement is required to support the increasing EV adoption. The planning model adopted in this case study performed better than the model reported in [114-117]. The third case study predicted the charging demand in Helsinki using a hybrid Bayesian network and RF-based methodology. It was observed that the model used for prediction was efficient as compared with the model proposed in [101,102].

This has been an extensive review of the machine learning algorithms utilized for solving different charging infrastructure planning problems. We hope to provide researchers with an analysis of the suitability of machine learning algorithms for charging infrastructure planning problems. However, this work was limited to the charging infrastructure without vehicle grid integration (VGI).

\section{Conclusions}

The large-scale deployment of EVs requires sustainable charging infrastructure. This work systematically analyzed the machine learning applications for solving charging infrastructure planning problems. Qualitative and quantitative analyses of the research in this arena are provided herein. It can be seen that machine learning algorithms can be successfully applied in charging demand prediction and charging scheduling. Furthermore, three case studies that focus on charging infrastructure planning are presented. These explored charging station placement and charging demand prediction. We presented an extensive review of the machine learning algorithms utilized in solving different charging infrastructure planning problems. We hope to provide researchers with an analysis of the suitability of machine learning algorithms for charging infrastructure planning problems. However, this work was limited to charging infrastructures without vehicle grid integration (VGI).

We expect this work to attract the attention of researchers working in the areas of e-mobility, optimization, machine learning, power, and energy. Our future research will address some of the following key issues:

- The use of machine learning in localizing charging hotspots;

- A performance comparison of machine learning techniques combined with heuristics and metaheuristics applied to charging infrastructure planning problems;

- Planning V2G-enabled charging facilities.

Funding: This research is supported by European Research Consortium of Informatics and Mathematics (ERCIM).

Institutional Review Board Statement: Not applicable.

Informed Consent Statement: Not applicable.

Data Availability Statement: Not applicable.

Acknowledgments: The author would like to thank the European Research Consortium of Informatics and Mathematics (ERCIM).

Conflicts of Interest: The author declares no conflict of interest. 


\section{References}

1. Moriarty, P.; Honnery, D. Global transport energy consumption. In Alternative Energy and Shale Gas Encyclopedia; Wiley and Sons: Paris, France, 2016; pp. 651-656.

2. US Energy Information. Available online: https://www.eia.gov/energyexplained/use-of-energy/transportation.php (accessed on 16 October 2020).

3. Wang, Z.; Yang, L. Delinking indicators on regional industry development and carbon emissions: Beijing-Tianjin-Hebei economic band case. Ecol. Indic. 2015, 48, 41-48. [CrossRef]

4. Wang, Q.; Rongrong, L.; Rui, J. Decoupling and Decomposition Analysis of Carbon Emissions from Industry: A Case Study from China. Sustainability 2016, 8, 1059. [CrossRef]

5. Blesl, M.; Das, A.; Fahl, U.; Remme, U. Role of energy efficiency standards in reducing $\mathrm{CO}_{2}$ emissions in Germany: An assessment with TIMES. Energy Policy 2007, 35, 772-785. [CrossRef]

6. Deb, S.; Kalita, K.; Mahanta, P. Review of impact of electric vehicle charging station on the power grid. In Proceedings of the 2017 International Conference on Technological Advancements in Power and Energy (TAP Energy), Kollam, India, 21-23 December 2017.

7. González, L.G.; Siavichay, E.; Espinoza, J.L. Impact of EV fast charging stations on the power distribution network of a Latin American intermediate city. Renew. Sustain. Energy Rev. 2019, 107, 309-318. [CrossRef]

8. Garwa, N.; Niazi, K.R. Impact of EV on Integration with Grid System-A Review. In Proceedings of the 2019 8th International Conference on Power Systems (ICPS), Jaipur, India, 20-22 December 2019; pp. 1-6.

9. Deb, S.; Tammi, K.; Kalita, K.; Mahanta, P. Impact of electric vehicle charging station load on distribution network. Energies 2018, 11, 178. [CrossRef]

10. Deb, S.; Kalita, K.; Mahanta, P. Impact of electric vehicle charging stations on reliability of distribution network. In Proceedings of the 2017 International Conference on Technological Advancements in Power and Energy (TAP Energy), Kollam, India, 21-23 December 2017.

11. Di Paolo, M. Analysis of harmonic impact of electric vehicle charging on the electric power grid, based on smart grid regional demonstration project-Los Angeles. In Proceedings of the 2017 IEEE Green Energy and Smart Systems Conference (IGESSC), Long Beach, CA, USA, 6-7 November 2017; pp. 1-5.

12. Deb, S.; Kalita, K.; Mahanta, P. Distribution network planning considering the impact of electric vehicle charging station load. In Smart Power Distribution Systems; Academic Press: London, UK, 2019; pp. 529-553. Available online: https: / / www.sciencedirect. com/science/article/pii / B9780128121542000225 (accessed on 15 September 2021).

13. Deb, S.; Tammi, K.; Kalita, K.; Mahanta, P. Review of recent trends in charging infrastructure planning for electric vehicles. Wiley Interdiscip. Rev. Energy Environ. 2018, 7, e306. [CrossRef]

14. Sachan, S.; Deb, S.; Singh, S.N. Different charging infrastructures along with smart charging strategies for electric vehicles. Sustain. Cities Soc. 2020, 60, 102238. [CrossRef]

15. Bi, R.; Xiao, J.; Pelzer, D.; Ciechanowicz, D.; Eckhoff, D.; Knoll, A. A simulation-based heuristic for city-scale electric vehicle charging station placement. In Proceedings of the 2017 IEEE 20th International Conference on Intelligent Transportation Systems (ITSC), Yokohama, Japan, 16-19 October 2017; pp. 1-7.

16. Gatica, G.; Ahumada, G.; Escobar, J.W.; Linfati, R. Efficient heuristic algorithms for location of charging stations in electric vehicle routing problems. Stud. Inform. Control 2018, 27, 73-82. [CrossRef]

17. Deb, S.; Gao, X.Z.; Tammi, K.; Kalita, K.; Mahanta, P. Nature-Inspired Optimization Algorithms Applied for Solving Charging Station Placement Problem: Overview and Comparison. Arch. Comput. Methods Eng. 2019, 28, 91-106. [CrossRef]

18. Shahriar, S.; Al-Ali, A.R.; Osman, A.H.; Dhou, S.; Nijim, M. Machine Learning Approaches for EV Charging Behavior: A Review. IEEE Access 2020, 8, 168980-168993. [CrossRef]

19. Mishra, D. Estimation of the Net Charging Demand from Privately Owned Electric Vehicles Using Game Theory. Master's Thesis, Universitat Politècnica de Catalunya, Barcelona, Spain, 15 June 2017.

20. Xiong, Y.; Gan, J.; An, B.; Miao, C.; Bazzan, A.L. Optimal electric vehicle fast charging station placement based on game theoretical framework. IEEE Trans. Intell. Transp. Syst. 2017, 19, 2493-2504. [CrossRef]

21. Hardman, S.; Jenn, A.; Tal, G.; Axsen, J.; Beard, G.; Daina, N.; Figenbaum, E.; Jakobsson, N.; Jochem, P.; Kinnear, N.; et al. A review of consumer preferences of and interactions with electric vehicle charging infrastructure. Transp. Res. Part D Transp. Environ. 2018, 62, 508-523. [CrossRef]

22. Pagany, R.; Ramirez Camargo, L.; Dorner, W. A review of spatial localization methodologies for the electric vehicle charging infrastructure. Int. J. Sustain. Transp. 2019, 13, 433-449. [CrossRef]

23. Zhang, Q.; Li, H.; Zhu, L.; Campana, P.E.; Lu, H.; Wallin, F.; Sun, Q. Factors influencing the economics of public charging infrastructures for EV-A review. Renew. Sustain. Energy Rev. 2018, 94, 500-509. [CrossRef]

24. Khan, W.; Ahmad, A.; Ahmad, F.; Saad Alam, M. A comprehensive review of fast charging infrastructure for electric vehicles. Smart Sci. 2018, 6, 256-270. [CrossRef]

25. Das, H.S.; Rahman, M.M.; Li, S.; Tan, C.W. Electric vehicles standards, charging infrastructure, and impact on grid integration: A technological review. Renew. Sustain. Energy Rev. 2020, 120, 109618. [CrossRef]

26. Ji, Z.; Huang, X. Plug-in electric vehicle charging infrastructure deployment of China towards 2020: Policies, methodologies, and challenges. Renew. Sustain. Energy Rev. 2018, 90, 710-727. [CrossRef] 
27. Coffman, M.; Bernstein, P.; Wee, S. Electric vehicles revisited: A review of factors that affect adoption. Transp. Rev. 2017, 37, 79-93. [CrossRef]

28. Rahman, I.; Vasant, P.M.; Singh, B.S.M.; Abdullah-Al-Wadud, M.; Adnan, N. Review of recent trends in optimization techniques for plug-in hybrid, and electric vehicle charging infrastructures. Renew. Sustain. Energy Rev. 2016, 58, 1039-1047. [CrossRef]

29. Yang, T.; Long, R.; Li, W. Suggestion on tax policy for promoting the PPP projects of charging infrastructure in China. J. Clean. Prod. 2018, 174, 133-138. [CrossRef]

30. Rietmann, N.; Lieven, T. How policy measures succeeded to promote electric mobility-worldwide review and outlook. J. Clean. Prod. 2019, 206, 66-75. [CrossRef]

31. Ahmad, A.; Khan, Z.A.; Saad Alam, M.; Khateeb, S. A review of the electric vehicle charging techniques, standards, progression and evolution of EV technologies in Germany. Smart Sci. 2018, 6, 36-53. [CrossRef]

32. Gnann, T.; Stephens, T.S.; Lin, Z.; Plötz, P.; Liu, C.; Brokate, J. What drives the market for plug-in electric vehicles?-A review of international PEV market diffusion models. Renew. Sustain. Energy Rev. 2018, 93, 158-164. [CrossRef]

33. Ding, Z.; Teng, F.; Sarikprueck, P.; Hu, Z. Technical Review on Advanced Approaches for Electric Vehicle Charging Demand Management, Part II: Applications in Transportation System Coordination and Infrastructure Planning. IEEE Trans. Ind. Appl. 2020, 56, 2695-5703. [CrossRef]

34. Zhang, X.; Liang, Y.; Yu, E.; Rao, R.; Xie, J. Review of electric vehicle policies in China: Content summary and effect analysis. Renew. Sustain. Energy Rev. 2017, 70, 698-714. [CrossRef]

35. Youssef, C.; Fatima, E.; Chakib, A. A technological review on electric vehicle DC charging stations using photovoltaic sources. IOP Conf. Ser. Mater. Sci. Eng. 2018, 353, 012014. [CrossRef]

36. Du, J.; Ouyang, D. Progress of Chinese electric vehicles industrialization in 2015: A review. Appl. Energy 2017, 188, 529-546. [CrossRef]

37. Hardman, S. Understanding the impact of reoccurring and non-financial incentives on plug-in electric vehicle adoption-a review. Transp. Res. Part A Policy Pract. 2019, 119, 1-14. [CrossRef]

38. García-Álvarez, J.; González, M.A.; Vela, C.R. Metaheuristics for solving a real-world electric vehicle charging scheduling problem. Appl. Soft Comput. 2018, 65, 292-306. [CrossRef]

39. Zheng, Y.; Niu, S.; Shang, Y.; Shao, Z.; Jian, L. Integrating plug-in electric vehicles into power grids: A comprehensive review on power interaction mode, scheduling methodology and mathematical foundation. Renew. Sustain. Energy Rev. 2019, 112, 424-439. [CrossRef]

40. Jawad, S.; Liu, J. Electrical Vehicle Charging Services Planning and Operation with Interdependent Power Networks and Transportation Networks: A Review of the Current Scenario and Future Trends. Energies 2020, 13, 3371. [CrossRef]

41. Solanke, T.U.; Ramachandaramurthy, V.K.; Yong, J.Y.; Pasupuleti, J.; Kasinathan, P.; Rajagopalan, A. A review of strategic charging-discharging control of grid-connected electric vehicles. J. Energy Storage 2020, 28, 101193. [CrossRef]

42. Amjad, M.; Ahmad, A.; Rehmani, M.H.; Umer, T. A review of EVs charging: From the perspective of energy optimization, optimization approaches, and charging techniques. Transp. Res. Part D Transp. Environ. 2018, 62, 386-417. [CrossRef]

43. Limmer, S. Dynamic Pricing for Electric Vehicle Charging-A Literature Review. Energies 2019, 12, 3574. [CrossRef]

44. Ahmadi, A.; Tavakoli, A.; Jamborsalamati, P.; Rezaei, N.; Miveh, M.R.; Gandoman, F.H.; Heidari, A.; Nezhad, A.E. Power quality improvement in smart grids using electric vehicles: A review. IET Electr. Syst. Transp. 2019, 9, 53-64. [CrossRef]

45. Ma, C.T. System planning of grid-connected electric vehicle charging stations and key technologies: A review. Energies 2019, 12, 4201. [CrossRef]

46. Jia, Q.S.; Long, T. A review on charging behavior of electric vehicles: Data, model, and control. Control. Theory Technol. 2020, 18, 217-230. [CrossRef]

47. Panchal, C.; Stegen, S.; Lu, J. Review of static and dynamic wireless electric vehicle charging system. Eng. Sci. Technol. 2018, 21, 922-937. [CrossRef]

48. Khan, S.; Ahmad, A.; Ahmad, F.; ShafaatiShemami, M.; Saad Alam, M.; Khateeb, S. A comprehensive review on solar powered electric vehicle charging system. Smart Sci. 2018, 6, 54-79. [CrossRef]

49. Triviño-Cabrera, A.; Aguado, J.A. Wireless Charging for Electric Vehicles in the Smart Cities: Technology Review and Impact. In Transportation and Power Grid in Smart Cities: Communication Networks and Services; IEEE: Piscataway, NJ, USA, 2018; pp. 411-426.

50. Khan, S.; Shariff, S.; Ahmad, A.; Saad Alam, M. A comprehensive review on level 2 charging system for electric vehicles. Smart Sci. 2018, 6, 271-293. [CrossRef]

51. Dietterich, T.G. Machine learning for sequential data: A review. In Joint IAPR International Workshops on Statistical Techniques in Pattern Recognition (SPR) and Structural and Syntactic Pattern Recognition (SSPR); Springer: Berlin/Heidelberg, Germany, 2002; pp. 15-30.

52. .Kotsiantis, S.B.; Zaharakis, I.D.; Pintelas, P.E. Machine learning: A review of classification and combining techniques. Artif. Intell. Rev. 2006, 26, 159-190. [CrossRef]

53. Mosavi, A.; Ozturk, P.; Chau, K.W. Flood prediction using machine learning models: Literature review. Water 2018, $10,1536$. [CrossRef]

54. Singh, A.; Thakur, N.; Sharma, A. A review of supervised machine learning algorithms. In Proceedings of the 2016 3rd International Conference on Computing for Sustainable Global Development (INDIACom), New Delhi, India, 16-18 March 2016; pp. 1310-1315. 
55. Choudhary, R.; Gianey, H.K. Comprehensive review on supervised machine learning algorithms. In Proceedings of the 2017 International Conference on Machine Learning and Data Science (MLDS), Noida, India, 14-15 December 2017; pp. 37-43.

56. Kotsiantis, S.B.; Zaharakis, I.; Pintelas, P. Supervised machine learning: A review of classification techniques. Emerg. Artif. Intell. Appl. Comput. Eng. 2007, 160, 3-24.

57. Gavankar, S.; Sawarkar, S. Decision tree: Review of techniques for missing values at training, testing and compatibility. In Proceedings of the 2015 3rd International Conference on Artificial Intelligence, Modelling and Simulation (AIMS), Kota Kinabalu, Malaysia, 2-4 December 2015; pp. 122-126.

58. Somvanshi, M.; Chavan, P.; Tambade, S.; Shinde, S.V. A review of machine learning techniques using decision tree and support vector machine. In Proceedings of the 2016 International Conference on Computing Communication Control and Automation (ICCUBEA), Pune, India, 12-13 August 2016; pp. 1-7.

59. Belgiu, M.; Drăguț, L. Random forest in remote sensing: A review of applications and future directions. ISPRS J. Photogramm. Remote Sens. 2016, 114, 24-31. [CrossRef]

60. Chen, C.C.; Schwender, H.; Keith, J.; Nunkesser, R.; Mengersen, K.; Macrossan, P. Methods for identifying SNP interactions: A review on variations of Logic Regression, Random Forest and Bayesian logistic regression. IEEE/ACM Trans. Comput. Biol. Bioinform. 2011, 8, 1580-1591. [CrossRef] [PubMed]

61. Bhavsar, H.; Panchal, M.H. A review on support vector machine for data classification. Int. J. Adv. Res. Comput. Eng. Technol. 2012, 1, 185-189.

62. Tomar, D.; Agarwal, S. Twin support vector machine: A review from 2007 to 2014. Egypt. Inform. J. 2015, 16, 55-69. [CrossRef]

63. Kataria, A.; Singh, M.D. A review of data classification using k-nearest neighbour algorithm. Int. J. Emerg. Technol. Adv. Eng. 2013, 3, 354-360.

64. Dhanabal, S.; Chandramathi, S. A review of various k-nearest neighbor query processing techniques. Int. J. Comput. Appl. 2011, 31, 14-22.

65. Li, N.; Shepperd, M.; Guo, Y. A systematic review of unsupervised learning techniques for software defect prediction. Inf. Softw. Technol. 2020, 122, 106287. [CrossRef]

66. Solorio-Fernández, S.; Carrasco-Ochoa, J.A.; Martínez-Trinidad, J.F. A review of unsupervised feature selection methods. Artif. Intell. Rev. 2020, 53, 907-948. [CrossRef]

67. Govender, P.; Sivakumar, V. Application of k-means and hierarchical clustering techniques for analysis of air pollution: A review (1980-2019). Atmos. Pollut. Res. 2020, 11, 40-56. [CrossRef]

68. Ko, Y.D. An efficient integration of the genetic algorithm and the reinforcement learning for optimal deployment of the wireless charging electric tram system. Comput. Ind. Eng. 2019, 128, 851-860. [CrossRef]

69. Pevec, D.; Babic, J.; Kayser, M.A.; Carvalho, A.; Ghiassi-Farrokhfal, Y.; Podobnik, V. A data-driven statistical approach for extending electric vehicle charging infrastructure. Int. J. Energy Res. 2018, 42, 3102-3120. [CrossRef]

70. Cohen-Addad, V.; Kanade, V.; Mallmann-Trenn, F.; Mathieu, C. Hierarchical clustering: Objective functions and algorithms. J. ACM 2019, 66, 1-42. [CrossRef]

71. Straka, M.; De Falco, P.; Ferruzzi, G.; Proto, D.; van der Poel, G.; Khormali, S.; Buzna, L'. Predicting popularity of EV charging infrastructure from GIS data. arXiv 2019, arXiv:1910.02498.

72. Frendo, O.; Graf, J.; Gaertner, N.; Stuckenschmidt, H. Data-driven smart charging for heterogeneous electric vehicle fleets. Energy AI 2020, 1, 100007. [CrossRef]

73. Duan, M.; Darvishan, A.; Mohammaditab, R.; Wakil, K.; Abedinia, O. 2018, A novel hybrid prediction model for aggregated loads of buildings by considering the electric vehicles. Sustain. Cities Soc. 2018, 41, 205-219. [CrossRef]

74. Majidpour, M.; Qiu, C.; Chu, P.; Gadh, R.; Pota, H.R. Modified pattern sequence-based forecasting for electric vehicle charging stations. In Proceedings of the 2014 IEEE International Conference on Smart Grid Communications (SmartGridComm), Venice, Italy, 3-6 November 2014; pp. 710-715.

75. Zhu, J.; Yang, Z.; Chang, Y.; Guo, Y.; Zhu, K.; Zhang, J. A novel LSTM based deep learning approach for multi-time scale electric vehicles charging load prediction. In Proceedings of the 2019 IEEE Innovative Smart Grid Technologies-Asia (ISGT Asia), Chengdu, China, 21-24 May 2019; pp. 3531-3536.

76. Li, Z.; Hou, X.; Liu, Y.; Sun, H.; Zhu, Z.; Long, Y.; Xu, T. A Prediction Method of Charging Station Capacity Based on Deep Learning. In Proceedings of the 2017 th International Conference on Information Science and Control Engineering (ICISCE), Changsha, China, 21-23 July 2017; pp. 82-84.

77. Zhu, J.; Yang, Z.; Guo, Y.; Zhang, J.; Yang, H. Short-term load forecasting for electric vehicle charging stations based on deep learning approaches. Appl. Sci. 2019, 9, 1723. [CrossRef]

78. Li, Y.; Huang, Y.; Zhang, M. Short-term load forecasting for electric vehicle charging station based on niche immunity lion algorithm and convolutional neural network. Energies 2018, 11, 1253. [CrossRef]

79. Chung, Y.W.; Khaki, B.; Chu, C.; Gadh, R. Electric vehicle user behavior prediction using hybrid kernel density estimator. In Proceedings of the 2018 IEEE International Conference on Probabilistic Methods Applied to Power Systems (PMAPS), Boise, ID, USA, 24-28 June 2018; pp. 1-6.

80. Mansour-Saatloo, A.; Moradzadeh, A.; Mohammadi-Ivatloo, B.; Ahmadian, A.; Elkamel, A. Machine learning based PEVs load extraction and analysis. Electronics 2020, 9, 1150. [CrossRef] 
81. Zhang, X. Short-term load forecasting for electric bus charging stations based on fuzzy clustering and least squares support vector machine optimized by wolf pack algorithm. Energies 2018, 11, 1449. [CrossRef]

82. Zhu, J.; Yang, Z.; Mourshed, M.; Guo, Y.; Zhou, Y.; Chang, Y.; Wei, Y.; Feng, S. Electric Vehicle Charging Load Forecasting: A Comparative Study of Deep Learning Approaches. Energies 2019, 12, 2692. [CrossRef]

83. Almaghrebi, A.; Aljuheshi, F.; Rafaie, M.; James, K.; Alahmad, M. Data-Driven Charging Demand Prediction at Public Charging Stations Using Supervised Machine Learning Regression Methods. Energies 2020, 13, 4231. [CrossRef]

84. Buzna, L.; De Falco, P.; Khormali, S.; Proto, D.; Straka, M. Electric vehicle load forecasting: A comparison between time series and machine learning approaches. In Proceedings of the 2019 1st International Conference on Energy Transition in the Mediterranean Area (SyNERGY MED), Cagliari, Italy, 28-30 May 2019; pp. 1-5.

85. Ai, S.; Chakravorty, A.; Rong, C. Household EV charging demand prediction using machine and ensemble learning. In Proceedings of the 2018 IEEE International Conference on Energy Internet (ICEI), Beijing, China, 21-25 May 2018 ; pp. 163-168.

86. Majidpour, M.; Qiu, C.; Chu, P.; Gadh, R.; Pota, H.R. Fast prediction for sparse time series: Demand forecast of EV charging stations for cell phone applications. IEEE Trans. Ind. Inform. 2014, 11, 242-250. [CrossRef]

87. García-Suárez, A.; Guisado-Lizar, J.L.; Diaz-del-Rio, F.; Jiménez-Morales, F. A Cellular Automata Agent-Based Hybrid Simulation Tool to Analyze the Deployment of Electric Vehicle Charging Stations. Sustainability 2021, 13, 5421. [CrossRef]

88. Dang, Q.; Wu, D.; Boulet, B. A Q-learning based charging scheduling scheme for electric vehicles. In Proceedings of the 2019 IEEE Transportation Electrification Conference and Expo (ITEC), Detroit, MI, USA, 19-21 June 2019; pp. 1-5.

89. Wang, F.; Gao, J.; Li, M.; Zhao, L. Autonomous PEV Charging Scheduling Using Dyna-Q Reinforcement Learning. IEEE Trans. Veh. Technol. 2020, 69, 12609-12620. [CrossRef]

90. Li, H.; Wan, Z.; He, H. Constrained EV Charging Scheduling Based on Safe Deep Reinforcement Learning. IEEE Trans. Smart Grid 2019, 11, 2427-2439. [CrossRef]

91. Zhang, C.; Liu, Y.; Wu, F.; Tang, B.; Fan, W. Effective Charging Planning Based on Deep Reinforcement Learning for Electric Vehicles. IEEE Trans. Intell. Transp. Syst. 2020, 22, 542-554. [CrossRef]

92. Dang, Q.; Wu, D.; Boulet, B. EV Charging Management with ANN-Based Electricity Price Forecasting. In Proceedings of the 2020 IEEE Transportation Electrification Conference, Expo (ITEC), Chicago, IL, USA, 23-26 June 2020; pp. 626-630.

93. Shaarbaf, M.R.; Ghayeni, M. Identification of the Best Charging Time of Electric Vehicles in Fast Charging Stations Connected to Smart Grid Based on Q-Learning. In Proceedings of the 2018 Electrical Power Distribution Conference (EPDC), Tehran, Iran, 9-10 May 2018; pp. 78-83.

94. Liang, Y.; Ding, Z.; Ding, T.; Lee, W.J. Mobility-Aware Charging Scheduling for Shared On-Demand Electric Vehicle Fleet Using Deep Reinforcement Learning. IEEE Trans. Smart Grid 2020, 12, 1380-1393. [CrossRef]

95. Wan, Z.; Li, H.; He, H.; Prokhorov, D. Model-free real-time EV charging scheduling based on deep reinforcement learning. IEEE Trans. Smart Grid 2018, 10, 5246-5257. [CrossRef]

96. Han, Y.; Zhang, X.; Zhang, J.; Cui, Q.; Wang, S.; Han, Z. Multi-Agent Reinforcement Learning Enabling Dynamic Pricing Policy for Charging Station Operators. In Proceedings of the 2019 IEEE Global Communications Conference (GLOBECOM), Waikoloa, HI, USA, 9-13 December 2019.

97. Shin, M.; Choi, D.H.; Kim, J. Cooperative Management for PV/ESS-Enabled Electric Vehicle Charging Stations: A Multiagent Deep Reinforcement Learning Approach. IEEE Trans. Ind. Inform. 2019, 16, 3493-3503. [CrossRef]

98. Wang, S.; Bi, S.; Zhang, Y.J.A. Reinforcement learning for real-time pricing and scheduling control in ev charging stations. IEEE Trans. Ind. Inform. 2019, 17, 849-859. [CrossRef]

99. Chen, W.; Zhuang, P.; Liang, H. Reinforcement Learning for Smart Charging of Electric Buses in Smart Grid. In Proceedings of the 2019 IEEE Global Communications Conference (GLOBECOM), Waikoloa, HI, USA, 9-13 December 2019.

100. Ramachandran, A.; Balakrishna, A.; Kundzicz, P.; Neti, A. Predicting Electric Vehicle Charging Station Usage: Using Machine Learning to Estimate Individual Station Statistics from Physical Configurations of Charging Station Networks. arXiv 2018, arXiv:1804.00714.

101. Lucas, A.; Barranco, R.; Refa, N. Ev idle time estimation on charging infrastructure, comparing supervised machine learning regressions. Energies 2019, 12, 269. [CrossRef]

102. Ma, T.Y.; Faye, S. Multistep Electric Vehicle Charging Station Occupancy Prediction using Mixed LSTM Neural Networks. arXiv 2021, arXiv:2106.04986.

103. Hajduk, P. Big Data for Activity Based Transport Models. Master's Thesis, Aalto University, Espoo, Finland, 10 December 2018.

104. Axhausen, K.W.; Gärling, T. Activity-based approaches to travel analysis: Conceptual frameworks, models, and research problems. Transp. Rev. 1992, 12, 323-341. [CrossRef]

105. Deb, S. A Novel Data Driven Methodology for Charging Hotspots Computation for the city of Helsinki. In Proceedings of the 3rd International Conference on Electrical, Communication and Computer Engineering (ICECCE), Kuala Lumpur, Malaysia, 12-13 June 2021; pp. 1-6.

106. Ranta, M.; Karvonen, V.; Potter, J.J.; Pasonen, R.; Pursiheimo, E.; Halmeaho, T.; Ponomarev, P.; Pihlatie, M. Method including power grid model and route simulation to aid planning and operation of an electric bus fleet. In Proceedings of the 2016 IEEE Vehicle Power and Propulsion Conference (VPPC), Hangzhou, China, 17-20 October 2016; pp. 1-5.

107. HSL. Open Data Platform of HSL. 2021. Available online: http:/ / dev.hsl.fi/ (accessed on 1 July 2021).

108. Available online: ABB_Complete-offer-ebus_FINAL_X3.pdf (accessed on 15 April 2021). 
109. Deb, S.; Ghosh, D.; Mohanta, D.K. Reliability analysis of PV cell, wind turbine and diesel generator by using Bayesian network. In Proceedings of the 2016 International Conference on Electrical, Electronics, and Optimization Techniques (ICEEOT), Chennai, India, 3-5 March 2016; pp. 2714-2719.

110. Deb, S.; Ghosh, D.; Mohanta, D.K. Adequacy analysis of stand alone hybrid microgrid by using Bayesian network. In Proceedings of the 2016 International Conference on Computation of Power, Energy Information and Commuincation (ICCPEIC), Melmaruvathur, India, 20-21 April 2016; pp. 331-336.

111. Ghosh, D.; Deb, S.; Mohanta, D.K. Reliability evaluation and enhancement of microgrid incorporating the effect of distributed generation. In Handbook of Distributed Generation; Springer: Cham, Switzerland, 2017; pp. 685-730.

112. Deb, S. A novel Bayesian Network and Random Forest Based Approach to predict the charging demand of private Electric Vehicles of Helsinki, Finland. IEEE Trans. Intell. Transp. Syst. 2021.

113. Helsinki Traffic Report I TomTom Traffic Index. Available online: https:/ / www.tomtom.com/en_gb/traffic-index/ (accessed on 30 June 2021).

114. Schmidt, M.; Zmuda-Trzebiatowski, P.; Kiciński, M.; Sawicki, P.; Lasak, K. Multiple-Criteria-Based Electric Vehicle Charging Infrastructure Design Problem. Energies 2021, 14, 3214. [CrossRef]

115. Szymańska, P.; Szczur, A.; Zmuda-Trzebiatowski, P. Kryteria oceny lokalizacji punktów ładowania samochodów elektrycznych. Studium przypadku: Sieć punktów ładowania w Poznaniu. Pr. Kom. Geogr. Komun. PTG 2019, 22, 20-33. [CrossRef]

116. Lewicki, W.; Drożdż, W.; Wróblewski, P.; Żarna, K. The Road to Electromobility in Poland: Consumer Attitude Assessment. Eur. Res. Stud. 2021, 24, 28-39. [CrossRef]

117. Deb, S. Machine Learning for Solving Charging Infrastructure Planning: A Comprehensive Review. In Proceedings of the 2021 5th International Conference on Smart Grid and Smart Cities (ICSGSC), Tokyo, Japan, 18-20 June 2021; pp. 16-22. 